\title{
Laser Management of Phenytion induced Gingival Enlargement in Autistic Child
}

\author{
Islam Kassem* \\ Faculty of Medicine Alexandria University, Egypt
}

Submission: October 28, 2017 Published: November 10, 2017

*Corresponding author: Islam Kassem, Faculty of Medicine Alexandria University, Egypt, Email: ikassem@dr.com

\begin{abstract}
Drug-induced gingival enlargement is a frequent complication of phenytoin anticonvulsant therapy. In severe cases, gingival hyperplasia can cause marked cosmetic deformity, and significant occlusal changes which severely restrict masticatory function. We describe a unique case of massive phenytoin-induced gingival overgrowth preventing erption of all teeth and subsequent dentofacial deformity. Carbon dioxide laser resection of the gingival enlargement, are discussed.
\end{abstract}

Keywords: Gingival Hyperplasia; Gingival Enlargement; $\mathrm{CO}_{2}$ Laser; Phenytion

\section{Introduction}

Anincreasingnumber ofmedicationsareassociated withgingival enlargement [1,2]. Drugs associated with gingival enlargement can be broadly divided into three categories: anticonvulsants, calcium channel blockers, and immunosuppressant's [2]. Phenytoin remains the drug of choice for treatment for grand mal, temporal lobe, and psychomotor seizures since it was first introduced in the 1930s [3-5]. The first reported cases of phenytoinassociated enlargement appeared more than 6 decades ago. Since then, other anticonvulsant agents have been introduced that have frequently been linked to clinically significant forms of gingival enlargement $[3,6,7]$. The most effective treatment of drug-related gingival enlargement is withdrawal or substitution of medication. When this treatment approach is taken, as suggested by a case report, it may take from several weeks for resolution of gingival lesions [4]. Unfortunately, not all patients respond to this mode of treatment, especially those with longstanding gingival lesions $[8,9]$. The use of carbon dioxide lasers has shown some utility for reducing gingival enlargement, an approach which provides rapid postoperative homeostasis [6].

\section{Case Report}

3 year male children refer to Maxillofacial Surgery department Alexandria University from Pediatric Dentistry Department. The parent complains of unerption of all deciduous teeth together with dento facial deformity, the child is autistic receiving anticonvulsive therapy (phenytoin) [10]. Intra oral examination shows tense fibrotic gingival, well developed ridge, averted upper li, anterior open bite (Figures $1 \& 2$ ). CT scan examination revealed a generalized gingival enlargement, gingival tissue cover the whole teeth at all aspects. All teeth are present, with labioversion inclination of upper teeth, both alveolar bone \& basal bone is normal (Figure 3). The fibrous tissue band was resected using Carbon dioxide laser using KLS Martin Carbon dioxide Laser device with an infrared wavelength of $10,600 \mathrm{~nm}$. Safety precaution is applied, teeth that are in close proximity to lased tissues should be protected. Common methods include draping moist gauze over the teeth (Figure 4). The new gingival margin was made by incising with the laser at 4 to $8 \mathrm{~W}$ in focused mode. Protection of the teeth is crucial and is achieved with either a thin freer elevator or a metal matrix band. When working in interproximal areas, an intermittent mode (20-millisecond pulses at 20 pulses per second) is done after the excess tissue was excised; the underlying hypertrophic tissue was sculpted appropriately. This process was performed in defocused mode at 6 to $10 \mathrm{~W}$.

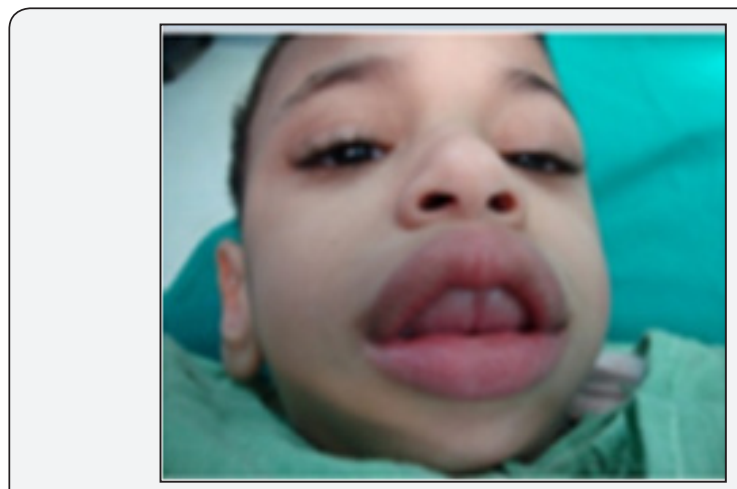

Figure 1: Clinical extra oral preoperative view. 


\section{Global Journal of Otolaryngology}

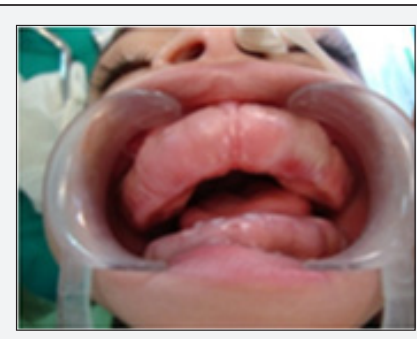

Figure 2 : Clinical intraoral view.

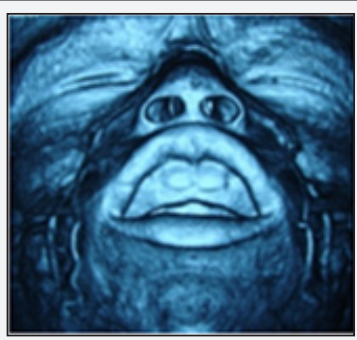

Figure 3 : Radiographic preoperative view show fibrous band over deciduous teeth.

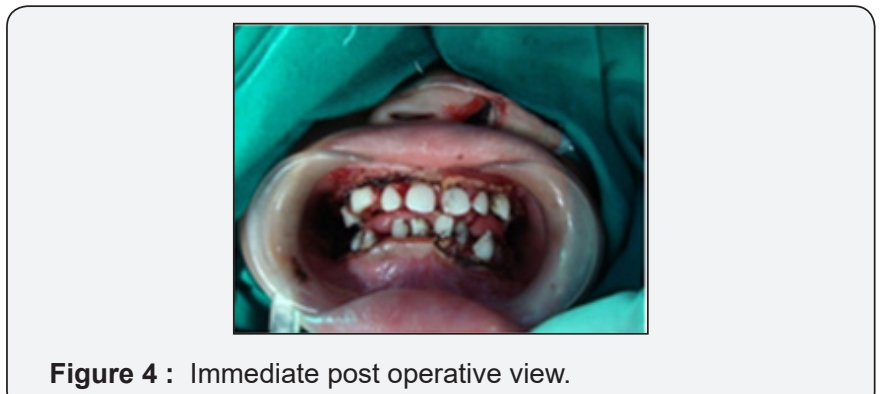

\section{Discussion}

The use of medications with the potential to contribute to the development of gingival overgrowth is likely increase in the years to come. Among the old and relatively new pharmacologic agents involved in gingival enlargement, overall, phenytoin still has the highest prevalence rate (approximately 50\%). Carbon dioxide lasers are now a standard of care for many oral and maxillofacial surgical procedures, as they are efficient for a variety of procedures. Despite the many advantages, there are also some disadvantages that must be weighed carefully before choosing this modality for patient treatment. As previously mentioned, healing from $\mathrm{CO}_{2}$ laser surgery is usually excellent, with decreased scarring and increased function; however, the speed of healing usually is prolonged compared with other types of wounds. This delay inhealingundoubtedly is due to the sealing of blood vessels and lymphatic's and the subsequent need for revascularization for healing. Laser management of drug induced gingival enlargement exhibit a solution for this health problem as its decrease bleeding, edema, pain \& recurrence provided good maintence and oral hygiene.

\section{References}

1. Ando A, Aoki A, Watanabe H, Ishikawa I (1996) Bactericidal Effect of Erbium YAG Laser on Periodontopathic Bacteria. Lasers Surg Med 19(2): 190-200.

2. Brunet L, Miranda J, Roset P, Berini L, Farre M, et al.(2001) Prevalence and risk of gingival enlargement in patients treated with anticonvulsant drugs. European Journal of Clinical Investigation 31(9): 781-788.

3. Brunet L, Miranda J, Farré M, Berini L, Mendieta C(1996) Gingival enlargement induced by drugs. Drug Safety 15(3): 219-231.

4. Fisher SE, Frame JW (1984) The effects of the carbon dioxide surgical laser on oral tissues. British Journal of Oral and Maxillofacial Surgery, 22(6): 414-425.

5. Garnett WR, ST Louis EK, Henry TR, Bramley T (2009) Transitional polytherapy, tricks of the trade for monotherapy to monotherapy AED conversions. Current Neuropharmacology 7(2): 83-95.

6. Gold SI, Vilardi MA (1994) Pulsed Laser Beam Effects on Gingiva. Journal of Clinical Periodontology 21(6): 391-396.

7. Guncu GN, Cxaglayan F, Dincxel A, Bozkurt A, Sayg S, et al. (2006) Plasma and gingival crevicular fluid phenytoin concentrations as risk factors for gingival overgrowth. Journal of Periodontology 77(12): 2005-2010.

8. Kanno CM, Oliveira JA, Garcia JF, Castro AL, Crivelini MM (2008) Effects of cyclosporine, phenytoin, and nifedipine on the synthesis and degradation of gingival collagen in tufted capuchin monkeys [Cebus apella]: histochemical and MMP- 1 and -2 and collagen I gene expression analyses. Journal of Periodontology 79: 114-122.

9. Kimball OP (1939) The treatment of epilepsy with sodium diphenyl hydantoinate. The Journal of the American Medical Association 112(13): 1244-1245.

10. Mcleod DE, Stoeckel D, COntreras J, Reyes E (2009) Severe postpartum gingival enlargement. Journal of Periodontology 80(8): 1365-1369. 
(C) Commons Attribution 4.0 License BY DOI: $10.19080 /$ GJ0.2017.11.555813
Your next submission with Juniper Publishers will reach you the below assets

- Quality Editorial service

- Swift Peer Review

- Reprints availability

- E-prints Service

- Manuscript Podcast for convenient understanding

- Global attainment for your research

- Manuscript accessibility in different formats

( Pdf, E-pub, Full Text, Audio)

- Unceasing customer service

Track the below URL for one-step submission https://juniperpublishers.com/online-submission.php 